\title{
Refractory Human Papillomavirus-Related Malignant Neoplasm
}

National Cancer Institute

\section{Source}

National Cancer Institute. Refractory Human Papillomavirus-Related Malignant

Neoplasm. NCI Thesaurus. Code C148512.

Human papillomavirus-related malignant neoplasm that does not respond to treatment. 